\title{
A PHYLOGENOMIC EXAMINATION OF PALMYRA ATOLL'S CORALLIMORPHARIAN INVADER
}

\author{
A THESIS SUBMITTED TO THE GRADUATE DIVISION OF THE UNIVERSITY OF HAWAI'I AT \\ MĀNOA IN PARTIAL FULFILLMENT OF THE REQUIREMENTS FOR THE DEGREE OF \\ MASTER OF SCIENCE
}

IN

MARINE BIOLOGY

April, 2021

By

Kaitlyn P. Jacobs

Thesis Committee:

Cynthia Hunter, Chairperson

Robert Toonen

Amanda Pollock

Keywords: corallimorph, RAD-seq, species deliniation, anthozoan genetics, Palmyra Atoll 
This work is dedicated to my dad, for helping me with my troubles and guiding me through my years. 


\section{Acknowledgements}

First and foremost I would like to thank my family, for their constant support and encouragement in everything that I decide to pursue. In addition I want to thank the friends that had to bear with me while I was at the height of this project, you are all troopers and the love doesn't go unnoticed.

I would like to extend a sincere mahalo to my thesis committee: Dr. Cynthia Hunter, Dr. Rob Toonen, and Dr. Amanda Pollock. Working on this thesis was a very formative process for me and each of you contributed uniquely to that, for which I am eternally grateful.

A big thank you to Mariana Rocha de Souza for contributing to the part of this work relating to Symbiodiniaceae sequencing and analysis. I would like to thank the HIMB EPSCoR core facility and the University of Hawai'i's Advanced Studies in Genomics, Proteomics, and Bioinformatics facility for their assistance with DNA sequencing. I also would like to give a large thank you to the United States Fish and Wildlife Service Palmyra team for collaboration and sample collection, specifically Stefan Kropidlowski, Danielle Cantrell, the amazing volunteers, and Tim Clark for collection from American Sāmoa. Also thank you to Thierry Work of the United States Geological Survey for background on the Palmyra outbreak and corallimorph tissue samples for practicing DNA extraction.

This research was supported by the University of Hawai'i at Mānoa School of Life Science's Edmondson Fund, and the Hawai' $i$ Institute of Marine Biology's Lord Scholarship. The remaining financial support came from NSF-OA\#1416889 and NOAA\#NA19NOS4780196 to Rob Toonen.

The views expressed herein are those of the authors and may not reflect the views of the USFWS or its sub-agencies. 


\begin{abstract}
The reefs at Palmyra Atoll, one of the northern Line Islands in the equatorial Pacific, have been undergoing a phase shift from scleractinian corals to a corallimorph-dominated benthos. It has been unclear whether there has been cryptic speciation or morphological plasticity leading to different ecotypes of Rhodactis howesii. Here, I use mitochondrial genomic analysis to assess species validation and underlying cause of morphological variation across the atoll. I mapped sequenced reads to Rhodactis indosinensis, $R$. howesii's closest recorded genomic taxon. In additon to one individual from American Sāmoa, I assessed phylogenetic relationships of published corallimorph genomes with those from Palmyra. There was no identifiable population structure within Palmyra, and available dinoflagellate symbiont communities were consistent among the sequenced individuals. There were notable differences in symbiont communities between Palmyra and American Sāmoa individuals, as well as six fixed nucleotide differences. I conclude that the lack of taxonomically validated genetic reference material together with vague species descriptions, morphological plasticity and overlap among morphological characters, combine to raise doubts about the validity of the currently accepted species name, $R$. howesii. Comparison of my results to all currently available genetic data for corallimorpharians suggests that the species at Palmyra is most closely related to an unidentified species of Rhodactis from Okinawa. However, taxonomically confirmed $R$. howesii is absent from genetic databases so no firm conclusions about species identification can yet be drawn. It seems clear that this group is in need of additional taxonomic work and a broad phylogenetic survey of taxa and geographic distribution would further my understanding of marine biodiversity, conservation, and invasion dynamics of this understudied group.
\end{abstract}




\section{Table of Contents}

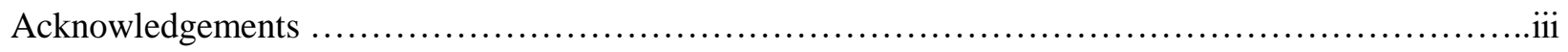

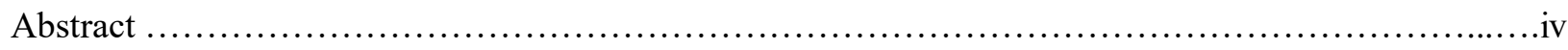

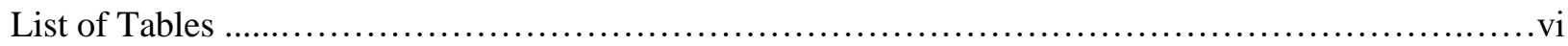

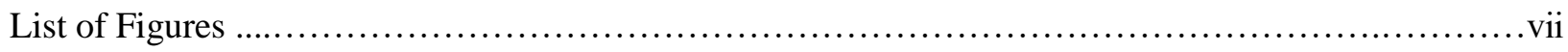

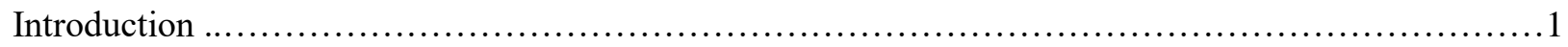

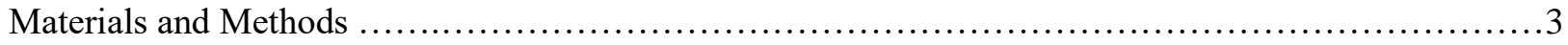

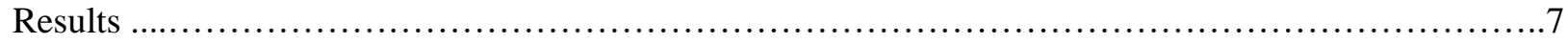

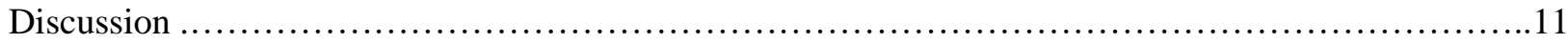

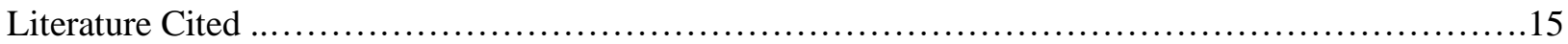

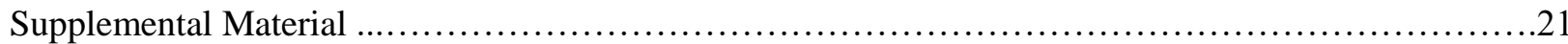




\section{List of Tables}

Table 1. Corallimorph sequence mapping statistics ..........................................

Table 2. Pairwise nucleotide differences between all analyzed species ............................. 7

Table S1. Collector information for sequenced corallimorph samples ..............................21

Table S2. Accession information for mitogenomes used in phylogenetic analyses .....................22

Table S3. rDNA and COI reference material and accession numbers............................22

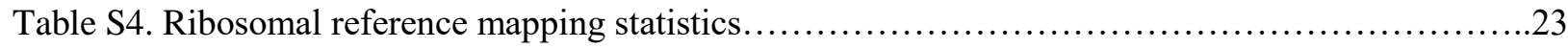

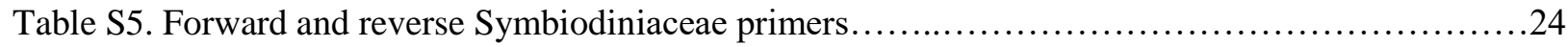




\section{List of Figures}

Figure 1. Corallimorphs at Palmyra and American Sāmoa .....................................................................

Figure 2. Collection sites of sequenced corallimorphs .....................................................................

Figure 3. Phylogenetic relationships of all corallimorph species relevant to this study based on available

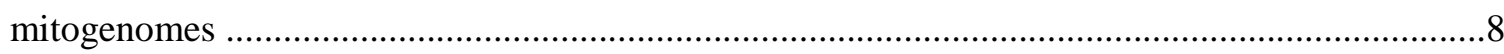

Figure 4. Phylogenetic relationships of corallimorphs based on COI sequences.......................................9

Figure 5. Symbiodiniaceae community relative abundance- grouped .......................................................10

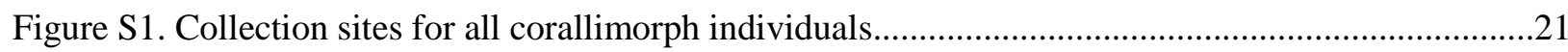

Figure S2. Complete corallimorph phylogeny from known data with collection sites............................24

Figure S3. Symbiodiniaceae community relative abundance- all species............................................26 


\section{Introduction}

Globally, coral reefs are subject to direct effects of human interaction, as well as indirect effects such as coastal development, runoff, and ocean warming and acidification (Spalding et al. 2017). One strategy to combat increasing anthropogenic pressures is the creation of large areas protected from fishing and visitation to offset the loss of coral reef habitats due to local and global stressors and increase spillover to adjacent habitats (Toonen et al. 2013; Cabral et al. 2020). One such area is the Pacific Remote Islands Marine National Monument, co-administered by the ME Fish and Wildlife Service (USFWS) and the National Oceanic Atmospheric Administration (NOAA). The Monument covers approximately $1,269,094 \mathrm{~km}^{2}$ in the Central Pacific, protecting multiple atolls, as well as biodiverse seamounts. Recent surveys show up to $200 \%$ increase in coral reef biodiversity since the Monument was established in 2001 (Kenyon et al. 2012).

Originally discovered by voyagers in 1802, Palmyra Atoll is the northern most atoll in the Line Island chain located in the equatorial Pacific. Palmyra Atoll National Wildlife Refuge (NWR) was created in 2001 following its purchase from the Fullard-Leo family by The Nature Conservancy in 2000, and has been protected ever since (Work et al. 2008; Collen et al. 2019). The atoll, which has been characterized as a nearly pristine coral reef ecosystem, has a productive trophic structure and high levels of coral cover and recruitment (Sandin et al. 2008). In the last decade, however, areas of the nearshore reef have been invaded by corallimorph colonies that can rapidly monopolize the benthos and reach $100 \%$ cover in some areas (Carter et al. 2019). There is concern that the resulting phase shift from scleractinian-dominated habitats may be irreversible due to a negative feedback loop of coral decline and subsequent algal, sponge, or corallimorph domination (Kelly et al. 2012).

Phase shifts have been shown to follow both pulse disturbances to the ecosystem as well as large scale events, such as shipwrecks and storms (Norström et al. 2009; Roff et al. 2015). In 1991, the fishing vessel Hui Feng I was intentionally grounded on the forereef of Palmyra Atoll; this wreck has been considered central to the outbreak of these corallimorphs (Work et al. 2008). Some believed that the grounding initiated the invasion, but the corallimorph was observed around the atoll before the shipwreck (Carter et al. 2019).

Corallimorphs are marine invertebrates that share traits with both anemones and scleractinian corals, possessing cnidae but lacking a calcareous skeleton (Muhando et al. 2002). They are able to reproduce asexually by budding and longitudinal fission, as well as through sexual reproduction (Chadwick-Furman and Spiegel 2000; Kuguru et al. 2002). Corallimorph growth and reproduction tends to increase in areas with higher nutrient loads and increased turbidity, conditions which tend to decrease competitive ability in scleractinian corals (Kuguru et al. 2002). Because of this adaptability, corallimorphs are excellent competitors; in addition to being able to kill corals directly, they can quickly move into disturbed areas and out-compete surrounding organisms (Chadwick-Furman and Spiegel 2000; Muhando et al. 2002).

A USFWS employee in 2004 identified the corallimorph at Palmyra as Rhodactis howesii, but permanent monitoring transects were not established until 2006 (T. Work, pers. comm.; Work et al. 2008). The shipwreck is believed to have favored the corallimorph, with some researchers proposing that copper or iron enrichment may have increased population growth rates, and others arguing that the disturbed habitat itself was ideal for colonization by this opportunistic species (Reichelt-Brushett and 
Harrison 1999; Work et al. 2008). Removal of the shipwreck in 2013 resulted in a marked decrease in corallimorph population density in the immediate vicinity (Carter et al. 2019). Despite the decline around the site of the wreck removal, there was spread to additional undisturbed sites where the corallimorph proved capable of overgrowing reef-building scleractinian corals (Work et al. 2018; Carter 2019). Control efforts using chlorine treatments were undertaken in 2018, but although successful, proved impractical due to limitations of the application and the scale of spread. The invasion remains a subject of considerable concern to resource managers, and research into new control methods is on-going (Work et al. 2018).

Two distinct morphs of $R$. howesii were recognized during initial monitoring surveys and also appear in the original species description (Saville-Kent 1893). One morph is small and vibrantly green in color and tends to occur in low densities that did not have displaced scleractinian corals. The second morph is dull brown with large, fleshy polyps that occur in dense colonies which monopolize space across broad areas (Figure 1) (A. Pollock, pers. obs.). Resource managers and researchers began to question whether the green and brown morphs with varying invasive tendencies represent different ecotypes of $R$. howesii, separate invasions, or perhaps even cryptic species. Corallimorpharians are notoriously difficult to identify, and the poorly resolved taxonomy of this group led to a preliminary genetic survey in an effort to confirm species identification, examine population genetic structure and determine possible origins of the invasion (Carter 2014). Unfortunately, these results were inconclusive. The target gene region, 18S, was highly conserved and uninformative, and there was little variation and no spatial structure among ITS1 and 5.8S sequences sampled from individuals at all sites around Palmyra Atoll (Carter 2014). The 28S sequence matched that of $R$. howesii published by Chen et al. (1996), but there were only a handful of corallimorpharian $28 \mathrm{~S}$ sequences against which to compare at the time. In addition, at the time of upload to GenBank this sequence was also mislabeled as a different Rhodactis species, and its validity in the database is still questionable (A. Carter, pers. comm.).

Here, I applied a reduced representation genomic sequencing approach (restriction-associated DNA sequencing, hereafter referred to as RAD-seq) to examine the current taxonomic classification of the invasive corallimorph identified as Rhodactis howesii. I also compare the samples at Palmyra Atoll to those in American Sāmoa as well as previously published studies. I initially set out to test whether the observed color morphs might be cryptic species or multiple introductions using RAD-seq as well, but as of 2019 observers noted that differences between the green and brown morphs were not as obvious as they had previously been and it had become difficult to tell them apart in the field. Therefore, after initially confirming no obvious genetic differences among the morphs, I did not pursue genetic analysis further. Finally, I also examined the diversity and identity of Symbiodiniaceae within these corallimorphs. These symbiontic dinoflagellates not only provide photosynthetic products that provide nutrients to the corallimorpharian host, but also have the capacity to affect host pigmentation and tentacle structure (Cha 2001; Kuguru et al. 2008; Hoadley et al. 2016), and I hypothesized that differences in symbiont community may help to explain the morphological and color differences. 


\section{Materials and Methods}

\section{Study Species}

Rhodactis howesii is a part of the family Discosomatidae, with a discoidal body shape, digit-form marginal tentacles, and branched distal tentacles (Cha 2001). The genus Rhodactis also contains three cnidae types: holotrichs, microbasic p- mastigophores, and microbasic b- mastigophores (Cha 2001). Unfortunately the original species description (Saville-Kent 1893) lacks sufficient morphological detail to confidently eliminate congeners (see Supplement.), and taxonomic opinions offered by experts are the most reliable information currently available (Cha 2001; Fautin 2013).

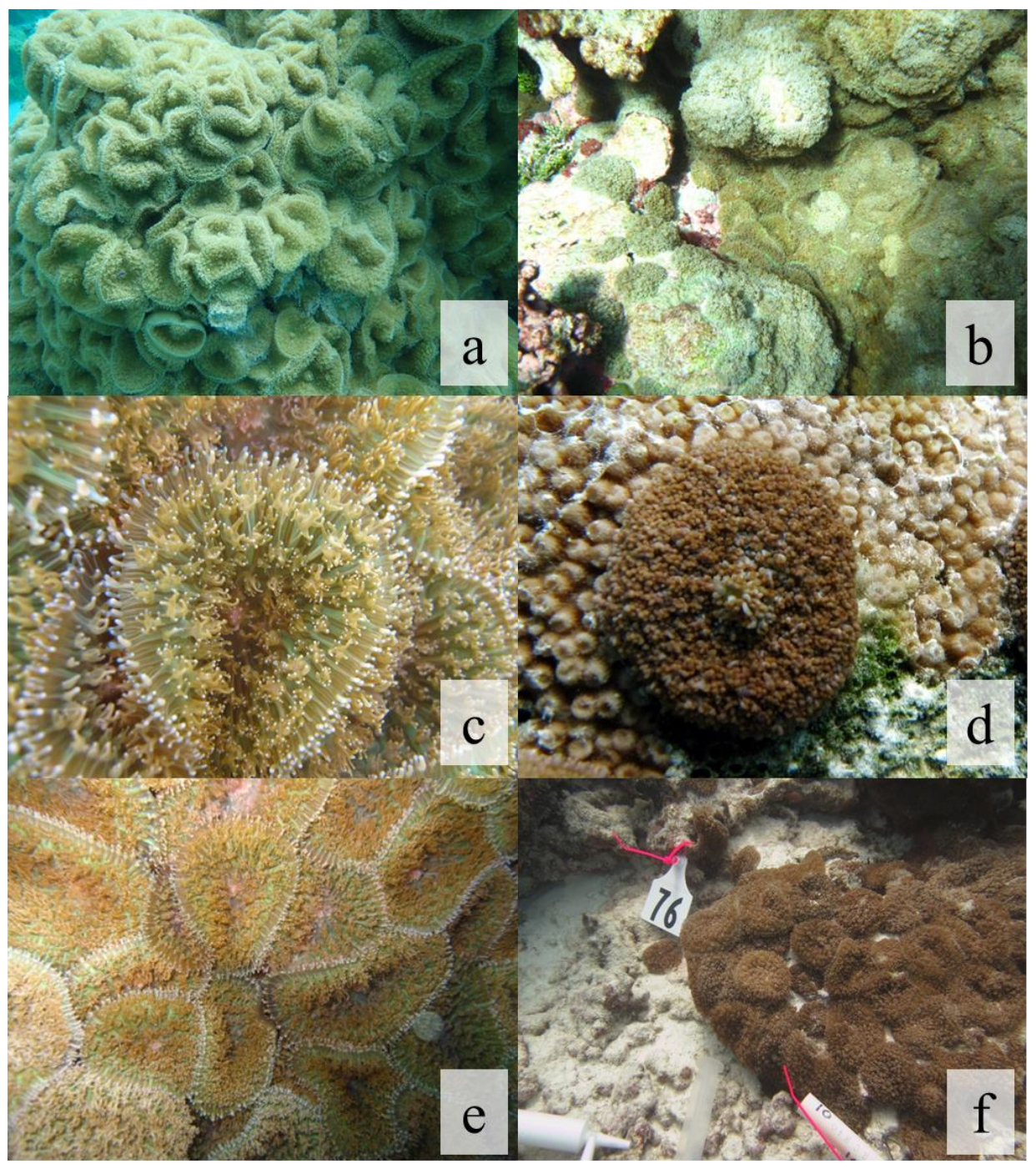

Figure 1. Corallimorphs at the Penguin Spit site on the reef of Palmyra Atoll (a), on a reef in Tutuila, American Sāmoa (b), putative green color morph on Palmyra (c \& e), brown color morph on Palmyra (d \& f). 


\section{Site Selection}

Two sites were chosen from separate geographical populations of corallimorpharians around the western reef terrace of Palmyra (Figure 2). Other sides of the island were inaccessible to volunteer collectors due to a lack of safe anchorage. Existing buoys marked these locations (Figure S1.). At each site, corallimorphs of the putative color morphs (green or brown) within a fifty-meter radius of the buoy were collected. Samples were also opportunistically collected from individuals in American Sāmoa by USFWS collaborators (Figure 2). 

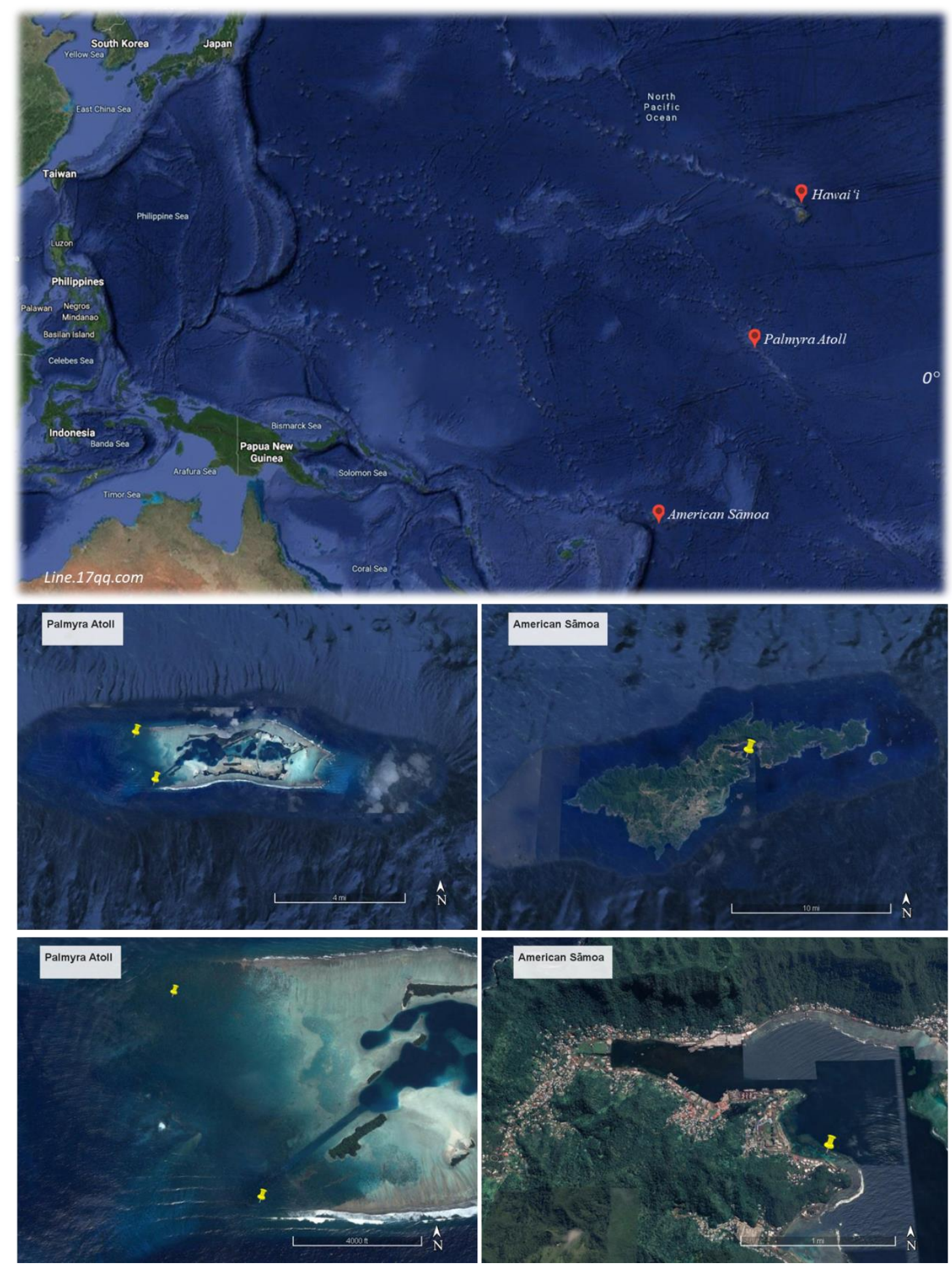

Figure 2. Collection sites of sequenced corallimorph individuals relative in the Pacific from Hawai'i (top); from Palmyra Atoll (left) and Tutuila, American Sāmoa (right). The uppermost point on the forereef at Palmyra is the site Crazy Corals (CC), the source of a green individual from a high density area, and the other is Penguin Spit, the source of one brown and one green individual (PSB \& PSG). 


\section{Sample Collection, DNA Extraction, and Quantification}

Tissue samples consisting of tentacle clips were collected from Palmyra Atoll and American Sāmoa, and placed in a DMSO salt saturated buffer (Gaither et al. 2011) at a 4:1 solution to tissue ratio for preservation and kept at room temperature until shipment to the Hawai' $i$ Institute of Marine Biology (HIMB), where they were stored at $-20^{\circ} \mathrm{C}$. Tissue was prepared for extraction by first being blotted on a Kimwipe tissue to remove extraneome mucome and allowed to dry for $5 \mathrm{~min}$. Extractions were then performed using the E.Z.N.A. Tissue Kit (Omega Bio-tek, Inc.) with an initial wash of $50 \mu 1$ of HPLC grade water followed by elution with $100 \mu \mathrm{l}$ to ensure high molecular weight DNA. Extracted DNA was visualized on a $1 \%$ agarose TAE gel, stained with GelRed (Biiotium, Inc.) next to a Quick-Load Purple 1 kb DNA ladder (New England BioLabs, Inc.) to assess quality.

\section{Library Preparation and Sequencing}

Reduced representation genomic sequencing employs the ez-RAD (Toonen et al. 2013) protocol of Knapp et al. (2016) to prepare RAD libraries for four high molecular weight samples selected to represent each of the green and brown color morphs, large geographical distance, and an individual from American Sāmoa. Briefly, DNA was digested with the frequent cutter DpnII restriction enzyme and quantified using a Qubit Fluorometer (Life Technologies). Post-digest the libraries were cleaned at a ratio of 1:1.8 (DNA:beads) with AMPure XP beads. Libraries were prepared using the KAPA Hyper Prep kit (Roche Sequencing and Life Science, Indianapolis, IN) following manufacturer protocols, and 325-700 bp fragments were isolated using a Pippin Prep (Sage Science, Inc.). Sequencing libraries were then amplified with nine rounds of PCR targeting $20 \mu \mathrm{l}$ of prepared DNA. Another cleaning with AMPure XP beads was performed post PCR with a 1:1 ratio. Libraries were validated by viewing on a 1\% agarose TAE gel as well as quantification with the Qubit Fluorometer (as above). Final samples contained 30.1, 32.6, 16.8, and 12.8 ng/ $\mu$ l of DNA for Crazy Corals (CC), Penguin Spit 1- brown morph (PSB), Penguin Spit 2- green morph (PSG), and American Sāmoa (AmS), respectively. Libraries were sequenced by the Advanced Studies in Genomics, Proteomics, and Bioinformatics (ASGPB) lab using an Illumina MiSeq (V3 2x300bp) at the University of Hawai'i at Mānoa.

\section{Bioinformatics}

Sequence data returned in FASTQ format by the core lab was first run through FASTQC to assess the quality of the reads (Andrews, 2010). The FASTQ reads were then imported to Geneious Prime (v2020.1.2, http://www.geneious.com, Kearse et al., 2012) and paired. The BBDuk (Bushnell, B. sourceforge.net/projects/bbmap/) was used to trim the reads and remove Illumina adapters, a minimum quality score, sequence length, and overlap of 20. Reads were mapped to the reference sequence of Rhodactis indosinensis using the Geneious mapper at medium-low sensitivity, iterating five times (Price et al. 2016). The nucleotide sequences were then aligned using the Geneious global consensus aligner with 93\% similarity. The concluding consensus sequences from each individual were then multiple aligned with Geneious to create the $R$. howesii mitochondrial genome consensus sequence (statistics from each of these steps are included in Table 1). Two short regions in the consensus were edited manually, due to high error rate at the ends of sequences and the difficulty of NGS sequencing to handle highly repetitive segments. If a polymorphism occurred after $>10$ repeating bases, it was manually deleted or edited to match the reference sequence (only four single nucleotides were removed this way). When evaluating SNP's across the consensus sequence, nucleotides were retained as polymorphisms if they had at least $3 \mathrm{x}$ coverage, were flanked by at least 10 good reads on either side, and were not within $20 \mathrm{bp}$ from the end of a read. 
To analyze phylogenetic relationships between the $R$. howesii mtDNA genome and other corallimorph references, tree models were analyzed using jModelTest (jModelTest 2.1.10; Guindon and Gascuel 2003; Darriba et al. 2012). The alignment was then put into RAxML (v 8.2.12, Stamatakis 2014) to compute maximum likelihoods and bootstrap values after 1,000 replications. RAxML was used through the toolkit provided by CIPRES science gateway (Miller et al. 2010). Tree data with bootstrap support values were visualized and edited in the program FigTree (v 1.4.4., Rambaut 2018), and imported into Inkscape to develop figures (Harrington et al. 2004). Pairwise nucleotide differences and phylogenetic tree support was done in MEGA (Kumar et al. 2018). COI barcode sequences for these samples were extracted from the mitochondrial genomes by mapping to the $R$. indosinensis COI segment using Geneious under the same conditions as previously mentioned. The COI tree was created using the BOLD database (Ratnasingham and Hebert 2007). Each individual was also read mapped to any corallimorph rDNA sequences (28S, 5.8S, 18S, ITS1, or ITS2) located in GenBank using the same Geneious parameters as listed above to create a comparative non-mitochondrial dataset (Table S4).

\section{Symbiodiniaceae identification}

The ITS2 region of Symbiodiniaceae ribosomal DNA was targeted for sequencing using Symbiodiniaceae specific primers 454-ITSinfor2 (5'-GAATTGCAGAACTCCGTG-3')and 454-ITS2-reverse (5'GGGATCCATATGCTTAAGTTCAGCGGGT-3') modified from Arif et al (2014) to include Nextera indexes to allow multiplexing (Table S1). Each $25 \mu \mathrm{L}$ PCR included the following components: $5 \mathrm{ng} / \mathrm{ul}$ of holobiont DNA, $5 \mu$ l of each 1.0 $\mu \mathrm{M}$ forward and reverse primer, and $12.5 \mu 1$ of HotSmart Taq 2X Master Mix. The PCRs were run with an initial melt of $95^{\circ} \mathrm{C}$ for $3 \mathrm{~min}$, followed by 25 cycles of $95^{\circ} \mathrm{C}$ for $30 \mathrm{~s}$, $55^{\circ} \mathrm{C}$ for $30 \mathrm{~s}$, and $72^{\circ} \mathrm{C}$ for $30 \mathrm{~s}$, and a final extension of $72^{\circ} \mathrm{C}$ for $5 \mathrm{~min}$. Amplification was checked visually by electrophorese on an agarose gel.

PCR products were cleaned with the Mag-Bind® TotalPure NGS (Omega Bio-tek, Inc.) following the clean-up protocol described in 16S Metagenomic Sequencing Library Preparation, quantified fluorescently using Qubit (Invitrogen), and pooled according to their DNA concentration. Sequencing library preparation followed the End repair and A-tailing and Adapter ligation steps described in KAPA hyper prep library (Knapp et al. 2016). Post ligation cleanup was done following the same bead protocol used previously.

Libraries were again sequenced at the UHM ASGPB sequencing facility. Sequences were demultiplexed using cutadapt and submitted to Symportal (Hume et al. 2019), a community driven database using NGS sequencing data to derive Symbiodiniaceae communities present using the ITS2 amplicon. 


\section{Results}

Four individuals were sequenced (Table 1), but the remaining collections were deemed unnecessary after learning that the color morphs were no longer as easily distinguishable in the field, and the discovery of Carter's thesis (2014) during data review revealed no indication of population structure.

Complete mitochondrial genomes were recovered from all three sequenced individuals from Palmyra and the one from American Sāmoa, with a ref-seq (coverage of at least one read per un-gapped sequence) of $100 \%$. Although the sample from Penguin Spit (PSB) had the highest number of reads, the sample from Crazy Corals (CC) had the highest number of mapped reads and the highest mean coverage (Table 1).

\begin{tabular}{|l|l|r|r|r|r|r|}
\hline Individual & Site & Sequence Reads & Mapped Reads & Coverage Mean & Pairwise Identity (\%) & Identical Sites (\%) \\
\hline American Sāmoa & Gataivai, American Sāmoa & $6,879,358$ & 16,664 & 187.3 & 67.8 & 99.5 \\
\hline CC & Crazy Corals, Palmyra & $8,047,024$ & 84,522 & 892.2 & 99.6 & 23.8 \\
\hline PSB & Penguin Spit, Palmyra & $8,577,144$ & 11,106 & 125.8 & 99.5 & 74.9 \\
\hline PSG & Penguin Spit, Palmyra & $8,009,596$ & 15,958 & 179.7 & 99.6 & 69.3 \\
\hline
\end{tabular}

Table 1. Individual corallimorph sequence reads were mapped to a Rhodactis indosinensis mitogenome reference (Table S2) using Geneiome Prime (v2020). For each individual, total number of reads sequenced was recorded, followed by the number of those reads that mapped to the $R$. indosinensis reference. Pairwise identity for each individual refers to the percent of reads at each nucleotide that were identical. Identical sites are those loci that have at least two mapped nucleotides that do not contain gaps and are identical.

The consensme sequence for the mitogenome of $R$. howesii generated from all four individuals was 20,354 base pairs in length, with $99.07 \%$ identical sites, $99.99 \%$ pairwise identity, and 0.36 expected errors. The three samples from Palmyra were identical, but the individual from American Sāmoa had six nucleotide differences across the mitogenome from them, all six widely separated throughout the consensus.

\section{Phylogenies}

The corallimorpharian phylogeny (Figure S2) based on all mitogenomes currently avialable shows a deep divergence with the Palmyra samples all falling within the same monophyletic clades. Corallimorphus profundus and Corynactis californica fall in the corallimorph clade most closely related to hard corals (Lin et al. 2014), and are evolutionarily divergent from the species of interest here. Therefore, $C$. profundus, C. californica, $R$. yuma, $R$. florida, and Pseudocorynactis sp. were removed from further analyses to better see the relationships between the $R$. howesii samples, which is supported by the pairwise nucleotide differences (Table 2).

\begin{tabular}{|c|c|c|c|c|c|c|c|c|c|c|c|c|c|}
\hline 1 A. fenestrafer & 1 & 2 & 3 & 4 & 5 & 6 & 7 & 8 & 9 & 10 & 11 & 12 & 13 \\
\hline 2 American Samoa & 0.010 & & & & & & & & & & & & \\
\hline 3 Palmyra- Crazy Corals & 0.010 & 0.000 & & & & & & & & & & & \\
\hline 4 C. profundus & 0.125 & 0.125 & 0.128 & & & & & & & & & & \\
\hline 5 C. californica & 0.138 & 0.135 & 0.136 & 0.283 & & & & & & & & & \\
\hline 6 D. nummiforme & 0.025 & 0.023 & 0.024 & 0.135 & 0.146 & & & & & & & & \\
\hline 7 Palmyra- Penguin Spit (B) & 0.011 & 0.001 & 0.001 & 0.129 & 0.141 & 0.024 & & & & & & & \\
\hline 8 Palmyra- Penguin Spit (G) & 0.011 & 0.001 & 0.000 & 0.129 & 0.141 & 0.024 & 0.000 & & & & & & \\
\hline 9 Pseudocorynactis sp. & 0.082 & 0.079 & 0.080 & 0.163 & 0.175 & 0.089 & 0.080 & 0.080 & & & & & \\
\hline 10 R. indosinensis & 0.012 & 0.002 & 0.002 & 0.130 & 0.143 & 0.026 & 0.002 & 0.002 & 0.082 & & & & \\
\hline 11 R. mussoides & 0.026 & 0.023 & 0.024 & 0.136 & 0.148 & 0.018 & 0.024 & 0.023 & 0.091 & 0.025 & & & \\
\hline 12 R. florida & 0.090 & 0.088 & 0.088 & 0.209 & 0.232 & 0.102 & 0.088 & 0.087 & 0.104 & 0.087 & 0.102 & & \\
\hline 13 R. yuma & 0.096 & 0.090 & 0.091 & 0.207 & 0.234 & 0.111 & 0.089 & 0.089 & 0.111 & 0.091 & 0.109 & 0.041 & \\
\hline
\end{tabular}

Table 2. Pairwise nucleotide differences between each corallimorph species assessed in the mitochondrial 
phylogeny at 39,777 sites. Darker shades indicate higher nucleotide differences, for example, a value of 0.283 would mean those two species have about $72 \%$ identical base pairs. Table is read by aligning numbers on top and left which represent the numbered species (i.e. The intersection of column 2 and row 3 is the difference between species 2- American Sāmoa and species 3-Palmyra CC). Yellow shaded boxes are the lowest values, and represent relationships between American Sāmoa and CC, CC and PSG, and PSB and PSG (top to bottom, left to right).

The smallest pairwise nucleotide differences (highest similarity) occured between the two color morphs (PSG and PSB) and the American Sāmoa sample with CC and PSG separately, followed closely by comparisons between Sāmoa and PSB, Sāmoa and PSG, and CC and PSB (Table 2).

Focusing on the monophyletic clade that contains the four samples characterized here (Figure 3), the phylogeny based on complete mitogenomes groups the Palmyra samples with Rhodactis indosinensis (branches in this clade have $\leq 75 \%$ bootstrap support). This tree splits out the individual from American Sāmoa, but with no congeners other than $R$. indosinensis against which to compare, this analysis offers little in terms of species-level identification of these corallimorphs.

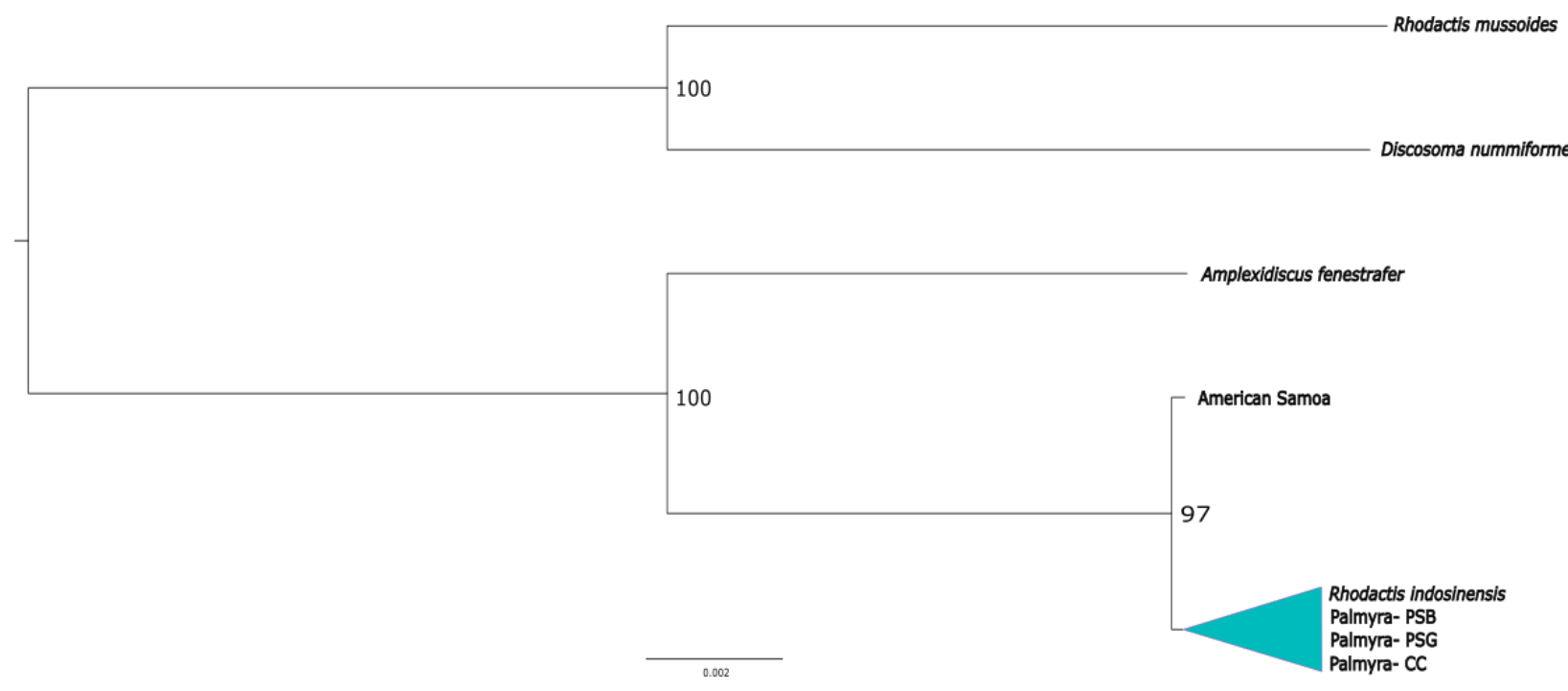

Figure 3. Phylogenetic relationships among corallimorphs based on currently available mitochondrial genomes. Branches $\leq 75 \%$ bootrsap support are collapsed.

Given the paucity of available mitogenomes for corallimorpharians, I extracted the rDNA loci from my samples and compared them to all other corallimorph sequences currently available in GenBank (Table S4). These loci again grouped my samples with other Rhodactis species, but phylogenic relationships showed low support and relationships differed among loci (Table S5). There is $100 \%$ sequence match to the only existing $R$. howesii $28 \mathrm{~S}$ reference, but it is only $211 \mathrm{bp}$ long, whereas there is also $100 \%$ sequence match to multiple other species (e.g. R. byroides and R. rhodostoma) based on longer portions of the rDNA (Table S5). Consistent with the mitogenome derived phylogenies, these data support both the Palmyra and American Sāmoa samples belonging to the genus Rhodactis, but offer little more in terms of species resolution. 
The most extensive reference database currently available for corallimorph species is the Barcode of Life Database (BOLD). Despite being the most extensive genetic sampling of corallimorph species available, BOLD does not include Rhodactis howesii, for which the only published sequence is the $211 \mathrm{bp}$ fragment of $28 \mathrm{~S}$ from Chen et al. (1996). This is also the sample for which the authors were uncertain of whether the species name had been corrected (A. Carter pers. comm.). Extracting the COI sequences from all four samples (Palmyra PSB, PSG, CC, and American Sāmoa) allowed me to compare my samples to other corallimorpharians across the globe. Because this database lacks any reference for $R$. howesii I can not confirm species identification, but as with the complete mitogenome phylogeny above, these samples show affinity to $R$. indosinensis (Figure 4). Using the BOLD sequence query, the closest match based on samples available in BOLD is an unidentified Rhodactis sp. 'OKRhod' collected from Okinawa, Japan (Fukami et al. 2008), whereas the $R$. howesii sequenced by Chen et al. (1996) was collected from Magic Island in the GBR, Australia.

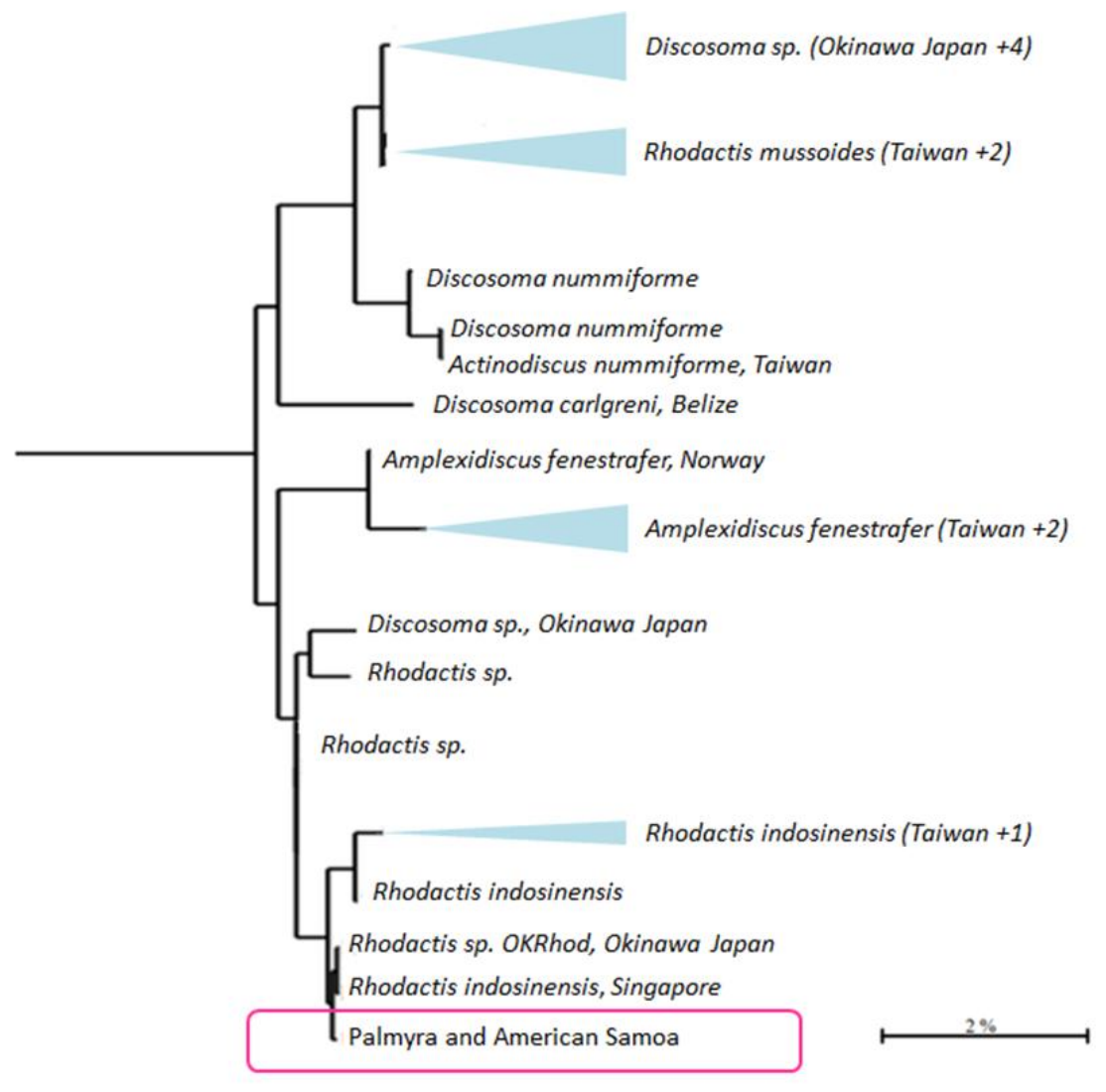

Figure 4. Phylogenetic relationships using COI sequences available in the BOLD systems database, where the box indicates the samples discussed in this study. Each of the four individuals were run through the sequence query separately, but all resulted in the same resulting phylogeny. Clades with minimal branch lengths are collapsed (number indicated by $+x$ ) for presentation.

\section{Symbiont communities}


Symportal results showed that all Palmyra samples had a diverse Symbiodiniaceae community, all belonging to the genus Cladocopium [formerly known as clade C (LaJeunesse et al. 2018)], while the corallimorph from American Sāmoa had only genus Durusdinium (clade D, type D4) (Figure 5.).

Symportal ITS2 type profiles show individuals CC and PG with highly similar symbiont communities, with CC showing the greatest number of $\mathrm{C} 1$ types across all four individuals (Figure S3).

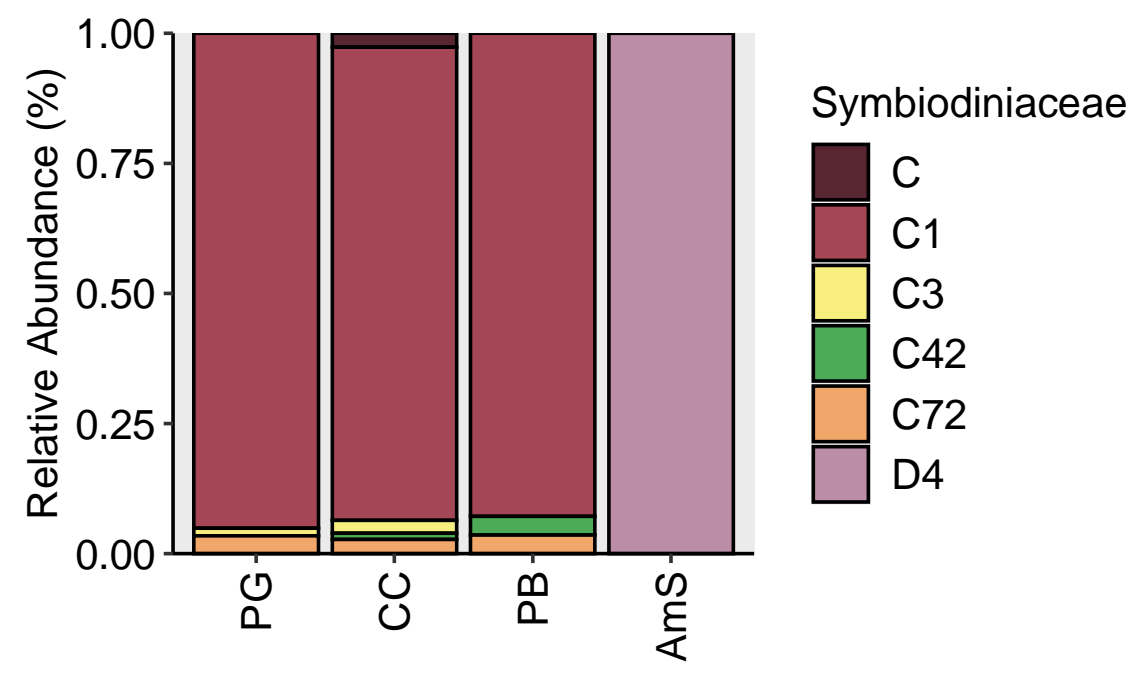

Figure 5. Symbiodiniaceae community relative abundance (\%) in corallimorphs of Palmyra (PG, CC, PB) and American Sāmoa. 


\section{Discussion}

Palmyra Atoll NWR within the Pacific Remote Islands Marine National Monument provides a desirable study site for those who seek to evaluate the structure and function of coral reef ecosystems with minimal direct human influence (Sandin et al. 2008; Lafferty et al. 2008; McCauley et al. 2010; Williams et al. 2011; Koweek et al. 2015). Such intact and diverse reefs were once thought more resistant to alien species (Mooney et al. 2005), but both sponges and corallimorphs are among those species that have successfully invaded Palmyra Atoll (Work et al. 2008; Knapp et al. 2011; Carter et al. 2019). Both of these groups are understudied and notoriously difficult to identify to species, even for taxonomic experts (Cha 2001; Knapp et al. 2015).

Corallimorpharian systematics have been evaluated using COI (Nilkerd et al. 2015; Crane et al. 2016), mitogenomes (Lin et al. 2014; this study), transcriptomes (Lin et al. 2017), 12S (Nilkerd et al. 2015), ITS (Chen et al. 1996; Oh et al. 2019), and IGR (Oh et al. 2019). Although these previous studies have shed light on the evolutionary split from scleractinian corals, there remains more detailed work to resolve incongruencies among nominal species within the Corallimorpharia. For example, in both my analysis and previous studies Rhodactis is polyphyletic with $R$. mussoides falling into a clade dominated by Discosoma rather than other Rhodactis species (Figures 3, 4, \& S5).

Corallimorpharian taxonomy has long been debated, and subject to change, due to a lack of skeletal structures to use as characters, broad overlap of morphologic characteristics, inconsistency of names and morphological plasticity, and brief and incomplete species and even genus descriptions (Cha 2001, Ocaña et al. 2017, Nilkerd et al. 2015). Most observations and taxonomic work on corallimorpharians to date has been done by scientists who specialized in Actinaria, with few specializing in this group specifically. This lack of taxonomic focus has led to some misclassifications and revisions, and it is only recently that morphological and genomic research has shown conclusively that Corallimorpharia is monophyletic and separate from both the Actiniaria and Scleractinia (Lin et al. 2014; Oh et al. 2019; Lin et al. 2017).

The World Register of Marine Species highlights a history of synonymizing in Rhodactis with species swapping into and out of the genus (Fautin 2013). R. howesii is recognized as a valid species since description by Saville-Kent in 1893, but a literature search turned up no other studies until the outbreak at Palmyra, with the only confirmed specimens being the original type collection from Australia (Fautin 2016). $R$. indosinenesis has been recorded from Cambodia, Vietnam, Japan, Micronesia, and Taiwan, having many of the same morphological and ecological characteristics (Fautin 2016, Lin et al. 2014, Crane et al. 2016, Oh et al. 2019). Saville-Kent (1893) mentions the similarity between marginal tentacles of $R$. howesii and $R$. rhodostoma.

To date, the only published genetic information on $R$. howesii comes from Chen et al. $(1995,1996)$ and subsequent phylogenetic analyses repeated this name using those same 28S, 5.8S, and ITS 1 sequences (Veron et al. 1996). In a more recent study with broader taxonomic sampling, Corallimorphus profundus was shown to be the corallimorpharian that is sister to the scleractinians, and diverged first in this ancient lineage. Analyzing phylogenetic relationships at both the nucleotide and protein levels, Rhodactis sp. (CASIZ 17155, Table S2) is most closely related to $R$. indosinenesis with a phylogeny (Figure S2) that matches the one produced in this study (Kitahara et al. 2014; Lin et al. 2014). Other studies using this 
same sequence from Rhodactis sp. show it to be sister taxa with $R$. indosinenesis (Oh et al. 2019), and in a monophyletic clade with A. fenestrafer (Nilkerd et al. 2015). Crane et al. (2016) collected a Rhodactis sp. from Okinawa, Japan and also report a sister relationship with $R$. indosinensis based on COI sequences. $R$. indosinenesis described in Oh et al. (2019) has " "marginal and discal tentacles brown, usually similar in color to oral disc. Tips of tentacles often a lighter shade or different in color (e.g., green)." which is also consistent with both the morphological description of the corallimorph observed in Palmyra and the original species description of $R$. howesii (see Online Resources). Oh et al. (2019) highlight that after detailing both internal and external characteristics, there were in some cases multiple morphotypes belonging to the same genetic species lineages, and concluded there was likely morphological plasticity in both $R$. indosinensis and $R$. inchoata.

Consistent with previous studies my work highlights the need for taxonomic revision of this group to unambiguously resolve the identity of this invasive corallimorpharian. My data show that the green and brown morphs have essentially identical mitogenomes that likely represent a single polymorphic species, and the fact that observers at Palmyra Atoll have found it increasingly difficult to distinguish the morphs provides additional support for this finding. Previous studies report that symbiotic dinoflagellates can alter host pigmentation and tentacle structure (Cha 2001, Kuguru et al. 2008, Hoadley et al. 2016) and I examined the symbiont communities to determine whether there were any differences among the morphs. In contrast to the hypothesis that differences in the symbiont community may help to explain the morphological differences, I find remarkably consistent symbiont communities among sampling locations and morphotypes (Fig. 6). Unfortunately, I do not have historical samples from when the morphs were more obvious, so cannot distinguish between the possibilities that the symbiont community has converged along with the polyp morphology through time, or that these morphs are not a result of thier symbiont community.

It is striking that the community of Symbiodiniaceae recovered from the invasive population at Palmyra differs from the sample at American Sāmoa. All samples from Palmyra host Cladocopium, expected due to this being the most common symbiont among shallow water invertebrates. Surprisingly, the sample from American Sāmoa contained only Durisdinium which is generally seen in deeper extremophilic environments (LaJeunesse et al. 2018). Symbiont diversity has been highlighted as one of the factors associated with resilience of reef corals in response to disturbance and anthropogenic impacts (e.g., Hill 1996, Baker 2004, Berkelmans and van Oppen, 2006, Nyström 2006, Baskett et al. 2009, Ziegler et al. 2018). In corallimorpharians specifically, survival under rapid environmental change and stress was attributed to symbiont shuffling (Kuguru et al. 2008), and symbiont composition has the capacity to affect host physiology (Hoadley et al 2016). Crazy Corals is considered a low density site in Palmyra whereas Penguin Spit is classified as high density, so the similarity of Cladocopium species and ITS2 relative abundance profiles between CC and PSG suggests that Symbiodiniaceae communities are not playing a large role in ability to overtake a reef. In additon, the presence of only one species difference between the two putative color morphs from Penguin Spit (C42au from PSB and C3ew from PSG) makes it unlikely that differences in symbiont makeup are responsible for the observed color differences. This conclusion is further supported by the phenotypic similarities and symbiont differences between Palmyra and Sāmoan corallimorphs (Figure 1).

Concordant differences in symbiont communities together with mitochondrial and nuclear differences between individuals from American Sāmoa and Palmyra highlight the need for broader taxonomic and 
geographic sampling to confirm whether such differences are within the normal range of variation seen within this group, or represent a species complex. Ultimately, these data cannot confirm that the invasive corallimorph at Palmyra Atoll is correctly identified as Rhodactis howesii. Genetic reference material aligns with $R$. indosinensis but no taxonomically confirmed samples exist in any database to confirm or exclude genetic similarity to $R$. howesii. Further, the morphological characters from the species descriptions could match several congeners including $R$. howesii, $R$. indosinensis or $R$. rhodostoma.

Regardless of an indisputable identification, this species of Rhodactis has been documented to rapidly monopolize disturbed habitat at Palmyra Atoll, leading to a phase shift on the reef (Work et al. 2008). Efforts to control the invasion included removal of the vessel at the epicenter of the initial spread and subsequent eradication efforts (Work et al. 2018). The removal of the wreck resulted in a decline in percent cover in that location, but increases in the sites of detection, percent cover and patch size continued at other locations around Palmyra (Carter 2019).

Palmyra lies in the middle of the North Equatorial Countercurrent, which flows eastward and separates the North and South Pacific tropical gyres (Hsin and Qiu 2012). This east-bound current from places like Taiwan and Japan may have been a potential source for central Pacific populations given the rafting ability of corallimorphs implies great dispersal potential (Chadwick-Furman et al. 2000). Palmyra's location along this current and on the equator also subjects it to an increase in nutrients and chlorophylls due to an upwelling gradient (Johnson et al. 2020).

Alternatively, a similar corallimorph invasion detected at Ulithi Atoll, Micronesia, was also found to be genetically identical to the Rhodactis species from Okinawa (the sequence that BOLD matched to the one discussed in this study) (Crane et al. 2016). Like Palmyra Atoll, Ulithi Atoll was also subject to WWII disturbance and high traffic from Japan (Mair 2008). Although often cited as a "near-pristine" coral reef, Palmyra Atoll was heavily impacted during the Second World War, and areas of post-war Palmyra show reduced water quality and poor circulation (Knapp et al. 2011). Corallimorphs are effective at colonizing reefs after disturbance events, which is a common denominator in documented phase shifts to corallimorph dominated benthos, and the genetic similarity of invasive populations in both these post-war atolls may not be a coincidence.

Here I show that from the individuals sampled from the green and brown morphs of Rhodactis, as well as from opposite ends of the Palmyra Atoll western terrace, show no evidence of cryptic divergence and appear to represent a single polymorphic species. Both holobiont RAD data and host mitogenomes show no cladal structure among Palmyra samples, but there were six fixed differences between the mitogenomes of American Sāmoa and the Palmyra Rhodactis samples. Concordant with the host genetics, assemblages of Symbiodiniaceae are strikingly different between corallimorpharians sampled at American Sāmoa and Palmyra, with the invasive population at Palmyra hosting a diversity of Cladocopium not seen in the sample from American Sāmoa. Insufficient genetic work has been done to determine whether six fixed differences falls within the range of mitochondrial variation expected among species of Rhodactis. The lack of taxonomically validated genetic reference material from this genus together with vague species descriptions, morphological plasticity and overlap among morphological characters combine to raise doubts about the validity of the currently accepted species name, $R$. howesii. Comparison of my results to all currently available genetic data for corallimorpharians suggests the invasive corallimorph at Palmyra is most closely related to an unidentified species of Rhodactis from 
Okinawa, but $R$. howesii is absent from genetic databases so no firm conclusions about species identification can yet be drawn. It is clear that Corallimorpharia is in need of taxonomically validated references sequences and that a broad phylogenetic survey of taxa and geographic distributions would further our understanding of marine biodiversity, conservation, and invasion dynamics in this understudied group. 


\section{Literature Cited}

16S Metagenomic Sequencing Library Preparation. (2013) https://www.illumina.com/content/dam/illuminasupport/documents/documentation/chemistry_documentation/16s/16s-metagenomic-library-prepguide-15044223-b.pdf

Arif, C., Daniels, C., Bayer, T., Banguera-Hinestroza, E., Barbrook, A., Howe, C. J., LaJeunesse, T.C., Voolstra, C.R. (2014) Assessing Symbiodinium diversity in scleractinian corals via nextgeneration sequencing-based genotyping of the ITS2 rDNA region. Molecular Ecology, 23: 4418-4433.

Andrews, S. (2010) FastQC: A Quality Control Tool for High Throughput Sequence Data. http://www.bioinformatics.babraham.ac.uk/projects/fastqc/

Baker, A.C. (2004) Symbiont diversity on coral reefs and its relationship to bleaching resistance and resilience. Coral health and disease (pp. 177-194). Springer, Berlin, Heidelberg.

Baskett, M.L., Gaines, S.D. and Nisbet, R.M. (2009) Symbiont diversity may help coral reefs survive moderate climate change. Ecological Applications, 19: 3-17.

Cabral, R.B., Bradley, D., Mayorga, J., Goodell, W., Friedlander, A.M., Sala, E., Costello, C. and Gaines, S.D. (2020) A global network of marine protected areas for food. Proceedings of the National Academy of Sciences. 117 (45) 28134-28139.

Carter, A. (2014) Invasion Mechanisms of the corallimorph, Rhodactis howesii, at Palmyra Atoll. Ph.D. thesis, University of California San Diego, p53.

Carter, A., Edwards, Clinton, B., Fox, M.D., Amir, C.G., Eynaud, Y., Johnson, M.D., Lewis, L.S., Sandin, S.A., and Smith, J.E. (2019) Changes in benthic community composition associated with the outbreak of the corallimorph, Rhodactis howesii at Palmyra Atoll. Coral Reefs 38:1267-1279.

Cha, Harim. (2001) Systematics of the Order Corallimorpharia (Cnidaria: Anthozoa). [unpublished dissertation]. University of Kansas.

Chadwick-Furman, N.E., and Spiegel, M. (2000) Abundance and clonal replication in the tropical corallimorpharian Rhodactis rhodostoma. Invertebrate Biology 119: 351-360.

Chadwick-Furman, N.E., Spiegel, M., and Nir, I. (2000) Sexual reproduction in the tropical corallimorpharian Rhodactis rhodostoma. Invertebrate biology 119: 361-369.

Chen, C.A., Odorico, D.M., Lohuis, M.T., Veron, J.E.N., and Miller, D.J. (1995) Systematic Relationships within the Anthozoa (Cnidaria: Anthozoa) Using the 5'-end of the 28S rDNA. Molecular Phylogenetics and Evolution 4: 175-183.

Chen, C.A, Willis, B.L., and Miller, D.J. (1996) Systematic relationships between tropical corallimorpharians (Cnidarian: Anthozoa: Corallimorpharia): Utility of the 5.8S and internal 
transcribed spacer (ITS) regions of the rRNA transcription unit. Bulletin of Marine Science 59: 196-208.

Collen, J.D., Garton, D.W., and Gardner, J.P.A. (2009) Shoreline changes and sediment redistribution at Palmyra Atoll (Equatorial Pacific Ocean): 1874-present. Journal of Coastal Research 25: 711722.

Crane, N.L., Paddack, M.J., Nelson, P.A., Abelson, A., Rulmal, J., and Bernardi, G. (2016) Corallimorph and Montipora Reefs in Ulithi Atoll, Micronesia: documenting unusual reefs. Journal of the Ocean Science Foundation 21: 10-17.

Darriba D., Taboada G.L., Doallo R., Posada D. (2012) jModelTest 2: more models, new heuristics and parallel computing. Nature Methods 9: 772.

Fautin, D. G. (2013) World List of Corallimorpharia. Rhodactis howesii Saville-Kent, 1893. Accessed through: World Register of Marine Species

Fautin, D.G. (2016) Catalog to families, genera, and species of orders Actiniaria and Corallimorpharia (Cnidaria: Anthozoa). Zootaxa 4145: 1-449.

Fukami, H., Chen, C.A., Budd, A.F., Collins, A., Wallace, C., Chuang, Y., Chen, C., Dai, C., Iwao, K., Sheppard, C., and Knowlton, N. (2008) Mitochondrial and nuclear genes suggest that stony corals are monophyletic but most families of stony corals are not (Order Scleractinia, Class Anthozoa, Phylum Cnidaria). PLoSOne 3:e3222.

Gaither, M.R., Szabo, Z., Crepeau, M.W., Bird, C.E., and Toonen, R.J. (2011) Preservation of corals in salt-saturated DMSO buffer is superior to ethanol for PCR experiments. Coral Reefs 30: 329-333.

Guindon S. and Gascuel O. (2003) A simple, fast and accurate method to estimate large phylogenies by maximum-likelihood. Systematic Biology 52: 696-704.

Harrington, B. et al. (2004-2005). Inkscape.

Hill, M.S. (1996) Symbiotic zooxanthellae enhance boring and growth rates of the tropical sponge Anthosigmella varians forma varians. Marine Biology 125: 649-654.

Hoadley, K.D., Pettay, D.T., Dodge, D., and Warner, M.E. (2016) Contrasting physiological plasticity in response to environmental stress within different cnidarians and their respective symbionts. Coral Reefs 35:529-542.

Hsin, Y. and Qui, B. (2012) Seasonal fluctuations of the surface North Equatorial Countercurrent (NECC) across the Pacific Basin. Journal of Geophysical Research: Oceans 117: 1-17.

Hume, B.C.C., Smith, E.G., Maren Ziegler, Hugh JM Warrington, John A. Burt, Todd C. LaJeunesse, Joerg Wiedenmann and Christian R. Voolstra. (2019) Symportal: A novel analytical framework and platform for coral algal symbiont next-generation sequencing ITS2 profiling". Molecular Ecology Resources, 19: 1063-1080. 
Johnson, M.D., Fox, M.D., Kelly, E.L.A., Zgliczynski, B.J., Sandin, S.A., and Smith, J.E. (2020) Ecophysiology of coral reef primary producers across an upwelling gradient in the tropical central Pacific. PlosOne 15: e0228448.

Kearse, M., Moir, R., Wilson, A., Stones-Havas, S., Cheung, M., Sturrock, S., Buxton, S., Cooper, A., Markowitz, S., Duran, C., Thierer, T., Ashton, B., Meintjes, P., and Drummond, A. (2012) Geneiome Basic: An integrated and extendable desktop software platform for the organization and analysis of sequence data. Bioinformatics Applications 28: 1647-1649.

Kelly, L.W., Barott, K.L., Dinsdale, E., Friedlander, A.M., Nosrat, B., Obura, D., Sala, E., Sandin, S.A., Smith, J.E., Vermeij, M.J.A., Williams, G.J., Willner, D., and Rohwer, F. (2011) Black Reefs: Iron-induced phase shifts on coral reefs. The International Society for Microbial Ecology Journal 6: 638-649.

Kenyon, J., Maragos, J., and Vroom, P. (2012) Monitoring supports establishment of Pacific Remote Islands Marine National Monument. Proceedings of the $12^{\text {th }}$ International Coral Reef Symposium, Cairns, Australia.

Kitahara, M.V., Lin, M., Foret, S., Huttley, G., Miller, D.J., and Chen, C.A. (2014) The "Naked Coral" Hypothesis Revisited - Evidence against Scleractinian Monophyly. PlosOne 9: e94774.

Knapp, I.S., Godwin, L.S., Smith, J.E., Williams, C.J., and Bell, J.J. (2011) Records of non-indigenous marine species at Palmyra Atoll in the ME Line Islands. Marine Biodiversity Records 4: 1-7.

Knapp, I.S., Forsman, Z.H., Williams, G.J., Toonen, R.J. and Bell, J.J. (2015) Cryptic species obscure introduction pathway of the blue Caribbean sponge (Haliclona (Soestella) caerulea),(order: Haplosclerida) to Palmyra Atoll, Central Pacific. PeerJ, 3: e1170.

Knapp, I.S.S., Puritz, J., Bird, C., Whitney, J., Sudek, M., Forsman, Z., and Toonen, R. (2016) ezRAD- an accessible next-generation RAD sequencing protocol suitable for non-model organsims_v3.2. dx.doi.org/10.17504/protocols.io.e9pbh5n.

Kuguru, B.L., Mgaya, Y.D., Ohman, M.C., and Wagner, G.M. (2004) The reef environment and competitive success in the Corallimorpharia. Marine Biology 145: 875-884.

Kuguru, B., Winters, G., Beer, S., Santos, S.R. and Chadwick, N.E. (2007) Adaptation strategies of the corallimorpharian Rhodactis rhodostoma to irradiance and temperature. Marine Biology, 151: 1287-1298.

Kuguru, B.L., Chadwick N.E., Achituv, Y., Zandbank, K., and Tchernov, D. (2008) Mechanisms of habitat segregation between corallimorpharians: photosynthetic parameters and Symbiodinium types. Marine Ecology Progress Series 269: 115-129.

Lafferty, K.D., Shaw, J.C. and Kuris, A.M. (2008) Reef fishes have higher parasite richness at unfished Palmyra Atoll compared to fished Kiritimati Island. EcoHealth, 5: 338-345. 
LaJeunesse, T.C. (2001) Investigating the biodiversity, ecology, and phylogeny of endosymbiotic dinoflagellates in the genus Symbiodinium using the ITS region: in search of a "species" level marker. Journal of Phycology, 37: 866-880.

LaJeunesse, T.C., Parkinson, J.E., Gabrielson, P.W., Jeong, H.J., Reimer, J.D., Voolstra, C.R., and Santos, S.R. (2018) Systematic Revision of Symbiodiniaceae Highlights the Antiquity and Diversity of Coral Endosymbionts. Current Biology 28: 2570-2580.

Lin, M., Kitahara, M.V., Luo, H., Tracey, D., Geller, J., Fukami, H., Miller, D.J., and Chen, C.A. (2014) Mitochondrial genome in the Scleractinia/Corallimorpharia complex: implications for coral phylogeny. Genome Biology and Evolution 6: 1086-1085.

Lin, M., Moya, A., Ying, H., Chen, C.A., Cooke, I., Ball, E.E., Foret, S., and Miller, D.J. (2017) Analyses of corallimorpharian transcriptomes provide new perspectives on the evolution of calcification in the Scleractinia (Corals). Genome Biology Evolution 9: 150-160.

Mair, M. (2008) Oil, fire, and fate: the sinking of the USS Mississinewa (AO-59) in WWII by Japan's secret weapon. SMJ Publishing, Platteville, Wisconsin, USA, 642 pp.

McCauley, D.J., Micheli, F., Young, H.S., Tittensor, D.P., Brumbaugh, D.R., Madin, E.M., Holmes, K.E., Smith, J.E., Lotze, H.K., DeSalles, P.A. and Arnold, S.N. (2010) Acute effects of removing large fish from a near-pristine coral reef. Marine Biology, 157: 2739-2750.

Miller, M.A., Pfeiffer, W., and Schwartz, T. (2010) Creating the CIPRES Science Gateway for inference of large phylogenetic trees. Proceedings of the Gateway Computing Environments Workshop (GCE) 14 Nov. 2010, New Orleans, LA pp 1 - 8.

Mooney, HA, RN Mack, JA McNeely, LE Neville, PJ Schei \& JK Waage, eds. (2005). Invasive alien species: a new synthesis IUCN Scientific Committee on Problems of the Environment. Island Press, Washington DC. 368 pp.

Muhando, C.A., Kuguru, B.L., Wagner, G.M., Mbije, N.E., Ohman, M.C. (2002) Environmental effects on the distribution of corallimorphs in Tanzania. Ambio 31: 558-561.

Nilkerd B., Swatdipong, A., Salaenoi, J., and Tunkijjanukij, S. (2015) Pilot survey of corallimorpharian (Cnidaria) diversity in the Gulf of Thailand. Kasetsart University Fisheries Research Bulletin 39: $30-42$.

Norström, A.V., Nyström, M., Lokrantz, J., and Folke, C. (2009) Alternative states on coral reefs: beyond coral-macroalgal phase shifts. Marine Ecology Progress Series 376: 295-306.

Nyström, M., (2006) Redundancy and response diversity of functional groups: implications for the resilience of coral reefs. AMBIO: A Journal of the Human Environment, 35: 30-35.

Ocaña, O., den Hartog, J.C., and Brito, A. (2017) Restoration of the genus Pseudocorynactis Den Hartog, 1980 and enmended diagnosis of the genera Corynactis Allman, 1846, Pseudocorynactis and Paracorynactis Ocaña, Den Hartog, Brito \& Bos, 2010. Rev. Acad. Canar. Cienc. 29, 9-20. 
Oh, R.M., Neo, M.L., Yap, N.W.L., Jain, S.S., Tan, R., Chen, C.A., and Huang, D. (2019) Citizen science meets integrated taxonomy to uncover the diversity and distribution of Corallimorpharia in Singapore. Raffles Bulletin of Zoology 67: 306-321.

Price, M.R., Forsman, Z.H., Knapp, I.S., Toonen, R.J., and Hadfield, M.G. (2016) The complete mitochondrial genome of Achatinella sowerbyana (Gastropoda: Pulmonata: Stylommatophora: Achatinellidae). Mitochondrial DNA Part B, 1:1, 666-668.

Ratnasingham, S., and Hebert, P. (2007) Barcoding BOLD: The Barcode of Life Data System. Molecular Ecology Notes 7:355-364.

Rambaut, Andrew. (2018) FigTree. http://tree.bio.ed.ac.uk/software/figtree/

Reichelt-Brushett, A.J., and Harrison, P.L. (1999) The effect of copper, zinc, and cadmium on fertilization success of gametes from Scleractinian reef corals." Marine Pollution Bulletin 38: 182-187.

Roff, G., Doropoulos, C., Zupan, M., Rogers, A., Steneck, R.S., Golbuu, Y., and Mumby, P.J. (2015) Phase shift facilitation following cyclone disturbance on coral reefs. Oecologia 178: 1193-1203.

Sandin, S.A., Smith, J.E., DeMartini, E.E., Dinsdale, E.A., Donner, S.D., Friedlander, A.M., Konotchick, T., Malay, M., Maragos, J.E., Obura, D., Pantos, O., Paulay, G., Richie, M., Rohwer, F., Schroder, R.E., Walsh, S., Jackson, J.B., Knowlton, N., and Sala, E. (2008) Baselines and degradation of Coral Reefs in the Northern Line Islands. PlosOne 3: e1548.

Saville-Kent, W. (1893) The Great Barrier Reef of Australia: Its products and potentialities. London.

Spalding, M., Burke, L., Wood, S.A., Ashpole, J., Hutchinson, J., and Ermgassen, P. (2017) Mapping the global value and distribution of coral reef tourism. Marine Policy 82:104-113.

Stamatakis, A. (2014) RAxML version 8: a tool for phylogenetic analysis and post-analysis of large phylogenies, Bioinformatics 30: 1312-1313.

Toonen, R. J., Puritz, J. B., Forsman, Z. H., Whitney, J. L., Fernandez-Silva, I., Andrews, K. R., \& Bird, C. E. (2013) ezRAD: a simplified method for genomic genotyping in non-model organisms. PeerJ 1:e203; DOI 10.7717/peerj.203.

Toonen, R.J., Wilhelm, T.A., Maxwell, S.M., Wagner, D., Bowen, B.W., Sheppard, C.R., Taei, S.M., Teroroko, T., Moffitt, R., Gaymer, C.F. and Morgan, L. (2013) One size does not fit all: the emerging frontier in large-scale marine conservation. Marine Pollution Bulletin, 77:7-10.

Veron, J.E., Odorico, D.M., Chen, C.A., and Miller, D.J. (1996) Reassessing evolutionary relationships of scleractinian corals. Coral Reefs 15:1-9.

Williams, G.J., Knapp, I.S., Aeby, G.S. and Davy, S.K. (2011) Spatial and temporal patterns of scleractinian coral, soft coral, and zoanthid disease on a remote, near-pristine coral reef (Palmyra Atoll, central Pacific). Diseases of Aquatic Organisms, 94: 89-100. 
Work, T. M., Aeby, G.S., and Maragos, J.E. (2008) Phase shift from a coral to a corallimorph-dominated reef associated with a shipwreck on Palmyra Atoll. Plos One 3: e2989.

Work, T.M., Aeby, G.S., Neal, B.P., Price, N.N., Conklin, E., and Pollock, A. (2018) Managing an invasive corallimorph at Palmyra Atoll National Wildlife Refuge, Line Islands, Central Pacific. Biological Invasions 20: 2197-2208.

Ziegler, M., Eguíluz, V.M., Duarte, C.M. and Voolstra, C.R. (2018) Rare symbionts may contribute to the resilience of coral-algal assemblages. The ISME Journal, 12: 161-172. 


\section{Supplemental Material}

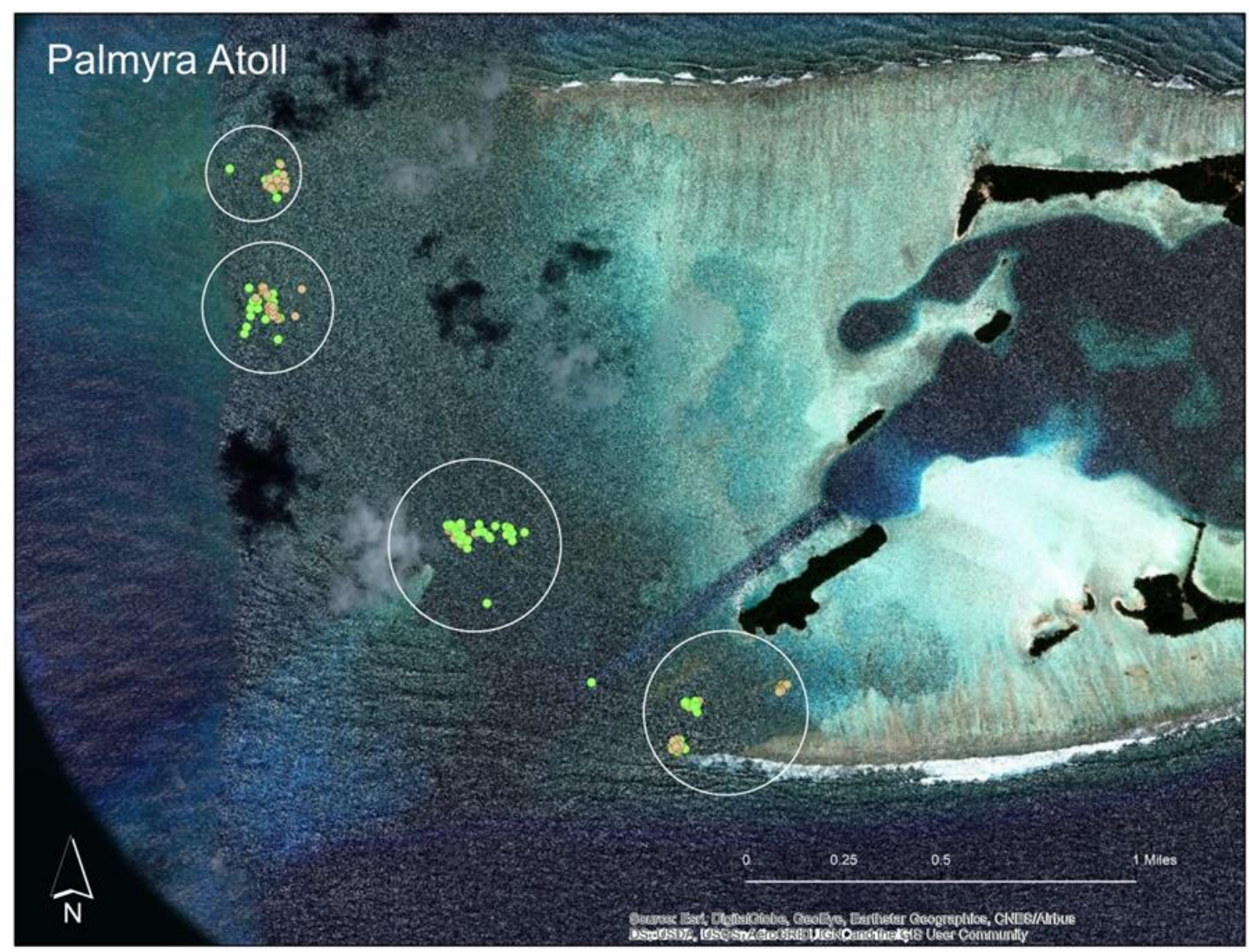

Figure S1. A map showing all corallimorph collection sites around Palmyra Atoll. Individuals selected for sequencing came from the lower-most site (Penguin Spit) and the upper-most site (Crazy Corals). Green and brown dots signify the putative different color morphs during collection.

\begin{tabular}{|l|l|l|}
\hline Sample & Site & Collector \\
\hline PSG & Penguin Spit, Palmyra & Fynn Peck, USFWS \\
\hline PSB & Penguin Spit, Palmyra & Fynn Peck, USFWS \\
\hline CC & Crazy Corals, Palmyra & Danielle Cantrell, USFWS \\
\hline AmS & Gataivai, American Samoa & Tim Clark, USFWS \\
\hline
\end{tabular}

Table S1. Collector information for each individual of corallimorph sequenced with corresponding sample name. 


\begin{tabular}{|c|c|c|c|}
\hline Species & Location Collected & Length (bp) Accession No. & Reference \\
\hline A. fenestrafer & Taiwan & $20,054 \mathrm{MH} 308002$ & Chi et al., 2019 \\
\hline R. indosinesis & Taiwan & 20,100 NC_027103 & Lin et al., 2014 \\
\hline D. nummiforme & unknown & 20,925 NC_027100 & Lin et al., 2014 \\
\hline R. mussoides & Taiwan & 20,826 NC_027104 & Lin et al., 2014 \\
\hline R. yuma & Taiwan & 22,015 NC_027106.1 & Lin et al., 2014 \\
\hline R. florida & Florida & 21,376 NC_008159 & Lin et al., 2014 \\
\hline Pseudocorynactis sp. & Scripps Aquarium, California & 21,239 KP938437 & Lin et al., 2014 \\
\hline C. californica & California & 20,715 NC_027102 & Lin et al., 2014 \\
\hline C. profundus & Antarctic Ocean & 20,488 KP938440 & Lin et al., 2014 \\
\hline Rhodactis sp. CASIZ 17155 & Florida, Bahamas & 20,093 DQ640647 & Medina et al. 2006 \\
\hline
\end{tabular}

Table S2. Mitogenomes used in phylogenetic analyses. Individuals in this study were reference mapped against $R$. indosinensis (NC_027103), and compared using both mitogenomes and BOLD COI sequences to Rhodactis sp. (DQ640647). After mapping, the individuals and each of the other species were aligned in Geneious (v2020) to create resulting phylogenies.

\begin{tabular}{|c|c|c|c|c|c|}
\hline Species & Sequence & Location Collected & Length (bp) & Accession No. & Reference \\
\hline \multirow{3}{*}{ A. fenestrafer } & $5.8 \mathrm{~S}$ & Pet store (locality: AU) & 178 & DQ831315 & Goddard et al, 2006 \\
\hline & $28 \mathrm{~S}$ & Museum in CA (locality: AU) & 299 & EF589076 & Cha, 2001 \\
\hline & $16 S$ & Museum in CA (locality: AU) & 788 & EF589053 & Cha, 2001 \\
\hline D. nummiforme & 18S, ITS1, 5.8S, 28S, ITS2 & Aka Island, Okinawa, Japan & 947 & AB441417 & Fukami et al., 2008 \\
\hline R. yuma & 285 & Swain Reef, GBR, AU & 218 & U69693 & Chen et al., 1995 \\
\hline R. florida & 18S, ITS1, 5.8S, 28S, ITS2 & La Parguera, Puerto Rico & 367 & GQ465063 & Torres-Pratts et al., 2011 \\
\hline \multirow{2}{*}{ R. rhodostoma } & $28 S$ & Unknown (locality: Red Sea) & 211 & EF589080 & Cha, 2001 \\
\hline & $18 \mathrm{~S}$ & Unknown (locality: Red Sea) & 1782 & EF589072 & Cha, 2001 \\
\hline R. howesii & $28 \mathrm{~S}$ & Magnetic Island, GBR, AU & 211 & RHU65512 & Chen et al., 1995 \\
\hline R. indosinensis & $\mathrm{CO} 1$ & Singapore & 664 & MN690353 & Cheong Aden Ip et al. 2019 \\
\hline Rhodactis sp. & $\mathrm{CO} 1$ & Okinawa, Japan & 609 & AB441625 & Fukami et al. 2008 \\
\hline
\end{tabular}

Table S3. rDNA and COI reference material and accession numbers 


\begin{tabular}{|c|c|c|c|c|c|}
\hline Reference & Sequence & Length (bp) & Individual & Mapped reads & Ref-seq (\%) \\
\hline \multirow{4}{*}{ Rhodactis howesii } & \multirow{4}{*}{$28 S$} & \multirow{4}{*}{211} & American Samoa & 186 & 100 \\
\hline & & & PSB & 0 & $N / A$ \\
\hline & & & PSG & 112 & 100 \\
\hline & & & $\mathrm{CC}$ & 28 & 100 \\
\hline \multirow{4}{*}{ Rhodactis bryoides } & \multirow{4}{*}{ 28S, 18S, 5.8S, ITS1, ITS2 } & \multirow{4}{*}{1,029} & American Samoa & 1,224 & 100 \\
\hline & & & PSB & 2 & 22.9 \\
\hline & & & PSG & 1,618 & 100 \\
\hline & & & $\mathrm{CC}$ & 158 & 100 \\
\hline \multirow{4}{*}{ Amplexidiscus fenestrafer } & \multirow{4}{*}{ 28S, 18S, 5.8S, ITS1, ITS2 } & \multirow{4}{*}{973} & American Samoa & 514 & 100 \\
\hline & & & PSB & 0 & $\mathrm{~N} / \mathrm{A}$ \\
\hline & & & PSG & 640 & 100 \\
\hline & & & $\mathrm{CC}$ & 70 & 95.1 \\
\hline \multirow{4}{*}{ Ricordea florida } & \multirow{4}{*}{$28 \mathrm{~S}, 18 \mathrm{~S}, 5.8 \mathrm{~S}, \mathrm{ITS} 1, \mathrm{ITS} 2$} & \multirow{4}{*}{367} & American Samoa & 16 & 50.1 \\
\hline & & & PSB & 0 & $\mathrm{~N} / \mathrm{A}$ \\
\hline & & & PSG & 32 & 50.7 \\
\hline & & & $\mathrm{CC}$ & 4 & 47.4 \\
\hline \multirow{4}{*}{ Discosoma nummiforme } & \multirow{4}{*}{ 28S, 18S, 5.8S, ITS1, ITS2 } & \multirow{4}{*}{947} & American Samoa & 436 & 100 \\
\hline & & & PSB & 0 & $\mathrm{~N} / \mathrm{A}$ \\
\hline & & & PSG & 496 & 99.7 \\
\hline & & & $\mathrm{CC}$ & 54 & 92.5 \\
\hline \multirow{4}{*}{ Rhodactis rhodostoma } & \multirow{4}{*}{$18 \mathrm{~S}$} & \multirow{4}{*}{1,782} & American Samoa & 2,564 & 100 \\
\hline & & & PSB & 7,906 & 99.3 \\
\hline & & & PSG & 5,836 & 100 \\
\hline & & & $\mathrm{CC}$ & 5,780 & 99.3 \\
\hline \multirow{4}{*}{ Rhodactis rhodostoma } & \multirow{4}{*}{$28 \mathrm{~S}$} & \multirow{4}{*}{221} & American Samoa & 154 & 100 \\
\hline & & & PSB & 0 & $\mathrm{~N} / \mathrm{A}$ \\
\hline & & & PSG & 190 & 100 \\
\hline & & & $\mathrm{CC}$ & 18 & 100 \\
\hline \multirow{4}{*}{ Ricordea yuma } & \multirow{4}{*}{$28 \mathrm{~S}$} & \multirow{4}{*}{218} & American Samoa & 186 & 100 \\
\hline & & & PSB & 0 & $\mathrm{~N} / \mathrm{A}$ \\
\hline & & & PSG & 114 & 100 \\
\hline & & & $\mathrm{CC}$ & 30 & 100 \\
\hline
\end{tabular}

Table S4. Ribosomal reference mapping statistics (reference data in Table S4) showing the length of each reference sequence and the number of corallimorph sequence reads mapped from each individual; Ref-seq is the percent of the reference that is covered by at least one read. 
Table S5. Forward 5'-3' and Reverse 3'-5' Symbiodiniaceae primers with attached indexes.

\begin{tabular}{lll}
\hline Sample & Forward primer with attached index & Reverse primer with attached index \\
\hline PSB & TCGCCTTAGAATTGCAGAACTCCGTG & AGCGTAGCGGGATCCATATGCTTAAGTTAGCGGGT \\
CC & TCGCCTTAGAATTGCAGAACTCCGTG & CAGCCTCGGGGATCCATATGCTTAAGTTCAGCGGGT \\
AmS & TCGCCTTAGAATTGCAGAACTCCGTG & TGCCTCTTGGGATCCATATGCTTAAGTTCAGCGGGT \\
PSG & TCGCCTTAGAATTGCAGAACTCCGTG & TCCTCTACGGGATCCATATGCTTAAGTTCAGCGGGT
\end{tabular}
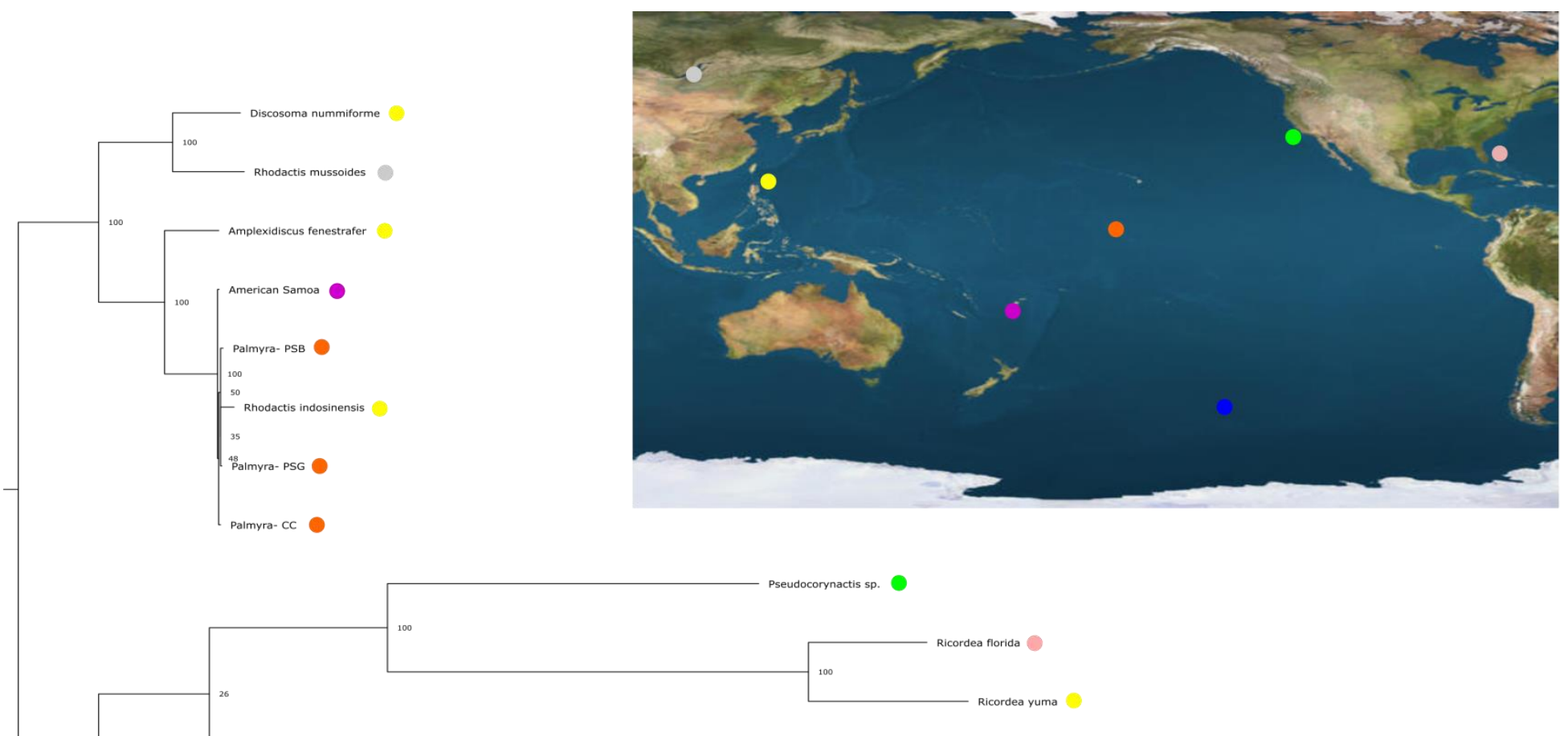
First morphological description of $R$. howesii (Saville-Kent 1893):

"This type, when expanded, is somewhat elevated and conical in outline; but it alters its shape, when contracted, to an almost perfect spheroid. The tentacles are thickly developed throughout the area of the disk. The inner circlet, situated in the immediate neighbourhood of the mouth, contains some four or five tentacles only, which are simple in character; the remaining tentacles are compound and irregularly palmate or pinnatifed in outline, consisting of a short cylindrical central shaft, around the distal half of which, from five or six to as many as twenty secondary pinnules may be developed. When the tentacles are expanded, these pinnules are elongate and subcylindrical, while in the contracted condition they are drawn in closely to the central shaft, and are distinctly capitate or spheroidal, as shown in Fig. $2 B$ of the plate referred to. In colour, this species was observed to exhibit two well-marked variations. In the one, the polyps were liver-brown thoroughout, excepting the tips of all the tentacle-pinnules, which were a brilliant golden, green. In the second variation the golden-green hue of the pinnule tips was replaced by a light pearl-grey. These two varieties of the same species were found growing massed together in patches of considerable size on the reefs adjacent to the Bay Rock lighthouse, Cleveland Bay, near Townsville. This species is provisionally referred to as the genus Rhodactis. In the type form of that genus, Rhodactis rhodostoma, the tentacles nearly agree in structure and disposition, except that simple tentacles are recorded as occurring on the outer margin of the disk and palmate ones around the oral orifice; in the present species the few existing simple tentacles are stationed immediately around the mouth as shown in Fig 2C. This anemone will probably have to be relegated to a distinct genus; in the meantime it is referred to its nearest known affinity under the title of Rhodactis howesii. The name here proposed for its specific distinction is associated with that of Prof. G. B. Howes, of the Royal College of Science, to whom the author is beholden for much aid in the compilation of this work." 


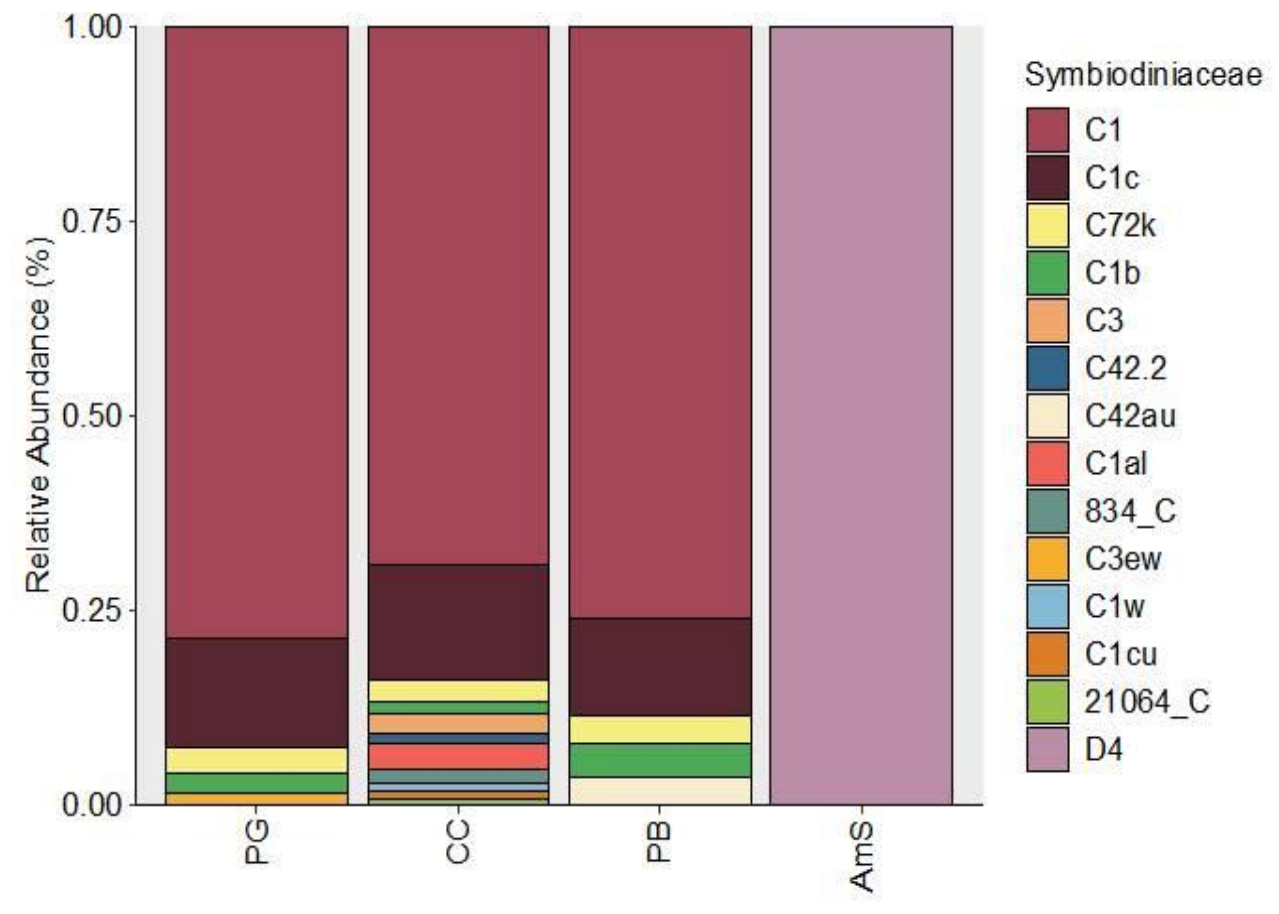

Figure S3. Symbiodiniaceae community relative abundance (\%) in corallimorphs of Palmyra (PG, CC, PB) and American Sāmoa expanded to show all types of each species. 